Metaphysics in Ordinary Language 
This page intentionally left blank 


\section{Metaphysics in Ordinary Language}

Stanley Rosen

Yale University Press

New Haven and London 
Published with assistance from the Ernst Cassirer Publicarions Fund.

Copyright $(\mathcal{C} 1999$ by Yale University.

All rights reserved.

This book may not be reproduced, in whole or in part, including illustrations, in any form (beyond that copying permitted by Sections 107 and 108 of the U.S. Copyright Law and except by reviewers for the public press), without written permission from the publishers.

Printed in the United States of America.

\section{Library of Congress Cataloging-in-Publication Data}

Rosen, Stanley, 1929-

Metaphysics in ordinary language / Stanley Rosen.

p. $\quad \mathrm{cm}$.

Includes bibliographical references and index.

ISBN 0-300-07478-6 (alk. paper)

1. Philosophy. I. Title.

$$
\begin{aligned}
& \text { B945.R526M48 } 1999 \\
& \text { I9I-dc2I }
\end{aligned}
$$

A catalogue record for this book is available from the British Library.

The paper in this book meets the guidelines for permanence and durability of the Committee on Production Guidelines for Book Longevity of the Council on Library Resources.

10 $\quad \begin{array}{lllllllll}9 & 8 & 7 & 6 & 5 & 4 & 3 & 2 & \text { I }\end{array}$ 
To Jebediah 
This page intentionally left blank 